This document was prepared in conjunction with work accomplished under Contract No. DE-AC09-96SR18500 with the U.S. Department of Energy.

This work was prepared under an agreement with and funded by the U.S. Government. Neither the U. S. Government or its employees, nor any of its contractors, subcontractors or their employees, makes any express or implied: 1 . warranty or assumes any legal liability for the accuracy, completeness, or for the use or results of such use of any information, product, or process disclosed; or 2 . representation that such use or results of such use would not infringe privately owned rights; or 3 . endorsement or recommendation of any specifically identified commercial product, process, or service. Any views and opinions of authors expressed in this work do not necessarily state or reflect those of the United States Government, or its contractors, or subcontractors. 
WSRC-STI-2007-00238

Revision 0

\title{
High Level Waste (HLW) Vitrification Experience in the US: Application of Glass Product/Process Control to Other HLW and Hazardous Wastes
}

Carol M. Jantzen and James C. Marra

Savannah River National Laboratory

Aiken, SC 29808

\begin{abstract}
Vitrification is currently the most widely used technology for the treatment of high level radioactive wastes (HLW) throughout the world. At the Savannah River Site (SRS) actual HLW tank waste has successfully been processed to stringent product and process constraints without any rework into a stable borosilicate glass waste since 1996. A unique "feed forward" statistical process control (SPC) has been used rather than statistical quality control (SQC). In SPC, the feed composition to the melter is controlled prior to vitrification. In SQC, the glass product is sampled after it is vitrified. Individual glass property models form the basis for the "feed forward" SPC. The property models transform constraints on the melt and glass properties into constraints on the feed composition. The property models are mechanistic and depend on glass bonding/structure, thermodynamics, quasicrystalline melt species, and/or electron transfers. The mechanistic models have been validated over composition regions well outside of the regions for which they were developed because they are mechanistic. Mechanistic models allow accurate extension to radioactive and hazardous waste melts well outside the composition boundaries for which they were developed.
\end{abstract}

\section{INTRODUCTION}

Borosilicate glasses have been used in the US and in Europe to immobilize radioactive HLW for ultimate geologic disposal. Vitrification has also been developed as a technology to immobilize low activity waste, low-level wastes, mixed (radioactive and hazardous) wastes, and TRU wastes in durable glass formulations for permanent disposal and/or long-term storage. Waste glass formulations must maximize the amount of waste to be vitrified so that waste glass volumes and the associated storage and disposal costs are reduced. Moreover, glass formulation optimization for HLW $[1,2,3]$ or other wastes must simultaneously balance multiple product/ process $(\mathrm{P} / \mathrm{P})$ constraints (Table I).

Table I. Waste Glass Product and Process Constraints

\begin{tabular}{|c|c|}
\hline Product Constraints & Process Constraints \\
\hline chemical durability & melt viscosity \\
\hline glass homogeneity & liquidus \\
\hline thermal stability & waste solubility \\
\hline regulatory compliance & melt temperature/corrosivity \\
\hline mechanical stability & radionuclide volatility \\
\hline & REDOX $^{*}$ \\
\hline
\end{tabular}

* controls foaming and melt rate 
Most $\mathrm{P} / \mathrm{P}$ properties, other than melt temperature, cannot be measured directly. The waste streams are often highly variable and difficult to characterize. In addition, in the US, the $\mathrm{P} / \mathrm{P}$ constraints must be satisfied to a very high degree of certainty $(>95 \%)$ as the canister geometry makes rework (remelting) of the product impossible. This requires a "systems approach" so that the $\mathrm{P} / \mathrm{P}$ constraints can be optimized simultaneously [1]. The "systems approach" ensures that the final product safeguards the public, and that the production process used is safe to operate.

The successful "systems approach" used at the Savannah River Sites HLW Defense Waste Processing Facility (DWPF) for the past 11 years is based on "feed forward statistical process control." The feed composition to the melter is controlled prior to vitrification and a confirmatory glass sample is taken only once every 2-3 years. The feed composition is used to calculate the $\mathrm{P} / \mathrm{P}$ properties of a melter feed from mechanistic $\mathrm{P} / \mathrm{P}$ models that relate the melt composition to the $\mathrm{P} / \mathrm{P}$ properties [2,3]. These models are the foundation of the SPC system used to monitor and control glass composition for HLW (Product Composition Control System) [4]. Over the last 11 years of radioactive operation $\sim 8.8$ million liters of HLW sludge have been vitrified at the DWPF into 4.2 millions kilograms of borosilicate glass.

The mechanistic models can be extrapolated well outside the glass composition range for which they were developed as will be shown in this study. These models can, therefore, be directly applied to other types of HLW, MW, and TRU wastes.

\section{PRODUCT CONSTRAINT: DURABILITY}

The most important glass product property is the glass durability. The durability of a waste glass is the single most important variable controlling release of radionuclides and/or hazardous constituents. The intrusion of groundwater into, and passage through, a waste form burial site in which the waste forms are emplaced is the most likely mechanism by which constituents of concern may be removed from the waste glass and carried to the biosphere. Thus it is important that waste glasses be stable in the presence of groundwater.

The DWPF durability model is known as the Thermodynamic Hydration Energy Reaction MOdel (THERMO ${ }^{\mathrm{TM}}$ ). [5,6] $\mathrm{THERMO}^{\mathrm{TM}}$ estimates the relative durability of silicate and borosilicate glasses based on their compositions. THERMO ${ }^{\mathrm{TM}}$ calculates the thermodynamic driving force of each glass component to hydrate based on the mechanistic role of that component during dissolution, e.g. ion exchange, matrix dissolution, accelerated matrix dissolution, surface layer formation, and/or oxidative dissolution. The overall tendency of a given glass to hydrate is expressed as a preliminary glass dissolution estimator, e.g. the change in the free energy of hydration of a glass $\left(\Delta \mathrm{G}_{\mathrm{p}}\right)$ based solely on its composition. For glasses that undergo accelerated matrix dissolution, an accelerated hydration free energy, $\Delta \mathrm{G}_{\mathrm{a}}$, is calculated from known strong base [SB] weak acid [WA] equilibrium. The $\Delta \mathrm{G}_{\mathrm{a}}$ term is additive to $\Delta \mathrm{G}_{\mathrm{p}}$ such that the overall durability of the glass, expressed as the final hydration free energy $\left(\Delta \mathrm{G}_{\mathrm{f}}\right)$, can be predicted, e.g. $\Delta \mathrm{G}_{\mathrm{f}}=\Delta \mathrm{G}_{\mathrm{p}}+\Delta \mathrm{G}_{\mathrm{a}}$. The more negative the $\Delta \mathrm{G}_{\mathrm{f}}$ the more readily the hydration reaction will occur and the less durable the glass. 
Recently, Jantzen and Pareizs [7] have proposed an Activated Complex Theory (ACT) model based on the early work of Helgeson [8] and the more recent work of Oelkers [9] on basalt glass dissolution. This approach attempts to define the activated complexes that participate in the irreversible formation of the glass gel layer. The formation of the hydrated gel layer is the irreversible step. The leached layer exhibits acid/base properties which are manifested as the $\mathrm{pH}$ dependence of the thickness and nature of the gel layer. The gel layer has been found to age into either clay mineral assemblages or zeolite mineral assemblages. The formation of one phase preferentially over the other has been experimentally related to changes in the $\mathrm{pH}$ of the leachant and related to the relative amounts of $\mathrm{Al}^{+3}$ and $\mathrm{Fe}^{+3}$ in a glass. The formation of clay mineral assemblages on the leached glass surface layers (lower $\mathrm{pH}$ and $\mathrm{Fe}^{+3}$ rich glasses) causes the dissolution rate to slow to a long-term "steady state" rate. The formation of zeolite mineral assemblages (higher $\mathrm{pH}$ and $\mathrm{Al}^{+3}$ rich glasses) on leached glass surface layers causes the dissolution rate to increase and return to the initial high forward rate. The return to the forward dissolution rate is undesirable for long-term performance of glass in a disposal environment.

The ACT approach [7] models the role of glass stoichiometry, in terms of the quasicrystalline mineral species (mineral moieties) in a glass. The stoichiometry of the mineral moieties in the parent glass appear to control the activated surface complexes that form in the leached layers, and these "mineral" quasi-crystals (some $\mathrm{Fe}^{+3}$ rich and some $\mathrm{Al}^{+3}$ rich) play a role in whether or not clays or zeolites are the dominant species formed on the leached glass surface. The chemistry and structure, in terms of Q distributions of the parent glass, are well represented by the atomic ratios of the glass forming components. Thus, glass dissolution modeling using simple atomic ratios is shown to represent the structural effects of the glass on the dissolution and the formation of activated complexes in the glass leached layer. This provides two different methods by which a linear glass durability model can be formulated. One based on the quasicrystalline mineral species in a glass and one based on cation ratios in the glass: both are related to the activated complexes on the surface by the law of mass action.

The ACT model included the DWPF type glasses used in the THERMO ${ }^{\mathrm{TM}}$ model, glasses from a round robin conducted at SRNL on the Waste Compliance Plan (WCP) glasses that span the entire range of the glasses anticipated for processing at the SRS [10], and glasses from a round robin conducted on the Environmental Assessment glass [11,12]. This included glasses made in crucibles and glasses made in large scale pilot scale melters. In addition, data from full scale canisters poured during the non-radioactive startup of the DWPF at the SRS during Qualification Runs (sections and grab samples), and radioactive glasses from the SRS M-Area facility [13] were included. While the DWPF glasses are enriched in $\mathrm{Fe}_{2} \mathrm{O}_{3}$ compared to $\mathrm{Al}_{2} \mathrm{O}_{3}$, the $\mathrm{M}$-Area glasses are enriched in $\mathrm{Al}_{2} \mathrm{O}_{3}$ and deficient in $\mathrm{Fe}_{2} \mathrm{O}_{3}$. The ranges of glass compositions modeled in THERMO ${ }^{\mathrm{TM}}$ and ACT are given in

Table II.

Modeling the leachate compositions from short and long term ASTM C1285 (PCT) tests for the glasses in ACT using the geochemical code EQ3/EQ6 provided data that was used to link the atomic ratios in ACT to leachate super saturation with respect to 
WSRC-STI-2007-00238

Revision 0

\begin{abstract}
either analcime or ferrite phases [7]. Thus glass composition, in terms of quasicrystalline structural ratios could be used to determine if a glass would form analcime and return to the forward rate or not. The model correctly predicted the well studied [14] French SM58 and SAN60 glasses (
\end{abstract}

Table II). The former did not return to the forward rate and the latter glass did.

\title{
PROCESS CONSTRAINTS: VISCOSITY AND RESISTIVITY
}

The viscosity of a waste glass melt as a function of temperature is the single most important variable affecting the melt rate and pourability of the glass. The viscosity determines the rate of melting of the raw feed, the rate of glass bubble release (foaming and fining), the rate of homogenization, and thus, the quality of the final glass product. If the viscosity is too low, excessive convection currents can occur, increasing corrosion/erosion of the melter materials (refractories and electrodes) and making control of the waste glass melter more difficult. The lowest glass viscosities in a waste glass melter are, therefore, conservatively set at $\sim 20$ poise at $\mathrm{T}_{\text {melt }}$. Waste glasses are usually poured continuously into steel canisters or cans for ultimate storage. Glasses with viscosities above 500 poise do not readily pour. Moreover, too high a viscosity can reduce product quality by causing voids in the final glass. A conservative maximum viscosity of 110 poise at $\mathrm{T}_{\text {melt }}$, is recommended for Joule heated waste glass melters.

The approach taken in the development of the viscosity and resistivity process models $[2,15,16]$ was based on glass structural considerations, expressed as a calculated non-bridging oxygen (NBO) term. This NBO parameter represents the amount of structural depolymerization in the glass. Calculation of the NBO term from the glass composition was combined with quantitative statistical analyses of response surfaces to express glass viscosity and glass resistivity as a function of both melt temperature and glass composition. The model was developed on as made compositions and recently revised [16] based on analyses of the same 41 non-radioactive waste glasses and frits (220 viscosity-temperature measurements). During revision the model was validated [16] on an additional 200 glasses (radioactive and non-radioactive and 1004 viscositytemperature pairs) (Table III). Uranium was shown to have no impact on glass viscosity and $\mathrm{ThO}_{2}$ at $<1 \mathrm{wt} \%$ had no impact on glass viscosity. At higher concentrations of $\mathrm{ThO}_{2}$ there was an impact of this component on glass viscosity.

\section{PROCESS CONSTRAINTS: LIQUIDUS}

A liquidus temperature model prevents melt pool or volume crystallization during operation. Volume crystallization needs to be avoided because it can involve almost simultaneous nucleation of the entire melt pool as volume crystallization can occur very rapidly. Furthermore, once spinel crystals are formed (the most ubiquitous liquidus phase occurring in US defense HLW), these crystals are refractory and cannot be redissolved into the melt pool. The presence of either the spinel or nepheline liquidus phases may cause the melt viscosity and resistivity to increase which may cause difficulty in discharging glass from the melter as well as difficulty in melting via Joule heating. Once a significant amount of volume crystallization has occurred and the resulting crystalline material has settled to the melter floor, melting may be inhibited and the pour spout may become partially or completely blocked making pouring difficult. 
The crystal-melt equilibria was modeled based on quasicrystalline concepts $[17,18]$. A pseudobinary phase diagram between a ferrite spinel (an incongruent melt product of transition metal iron rich acmite) and nepheline was defined. The pseudobinary lies within the $\mathrm{Al}_{2} \mathrm{O}_{3^{-}}$ $\mathrm{Fe}_{2} \mathrm{O}_{3}-\mathrm{Na}_{2} \mathrm{O}-\mathrm{SiO}_{2}$ quaternary system that defines the crystallization of basalt glass melts (note that the basalt glass system is used as an analogue for waste glass durability, liquidus, and the prevention of phase separation). The liquidus model developed based on these concepts has been used to prevent unwanted crystallization in the DWPF HLW melter for the past six years while allowing $>10 \mathrm{wt} \%$ higher waste loadings to be processed. The liquidus model and the pseudobinary are shown $[17,18]$ to be consistent with all of the thermal stability data generated on DWPF HLW glasses. The model ranges developed on 105 different glass compositions and validation ranges (161 glasses) are given in Table IV.

Table II. Oxide Ranges of Durability Model and Validation Glasses Compared to those of Van Isenghem and Grambow [14]

\begin{tabular}{|c|c|c|c|c|c|}
\hline $\begin{array}{l}\text { Oxide } \\
\text { (wt \%) }\end{array}$ & $\begin{array}{l}\text { THERMO } \\
\text { Model Range } \\
\end{array}$ & $\begin{array}{c}\text { THERMO }^{\mathrm{TM}} \\
\text { Validation }\end{array}$ & $\begin{array}{l}\text { ACT Model } \\
\text { Range }\end{array}$ & SM58 & SAN60 \\
\hline $\mathrm{Al}_{2} \mathrm{O}_{3}$ & $1.36^{t}-13.90$ & $0.56^{\ddagger}-22.80$ & $2.99^{*}-25.04$ & $1.20^{f}$ & 18.10 \\
\hline $\mathrm{B}_{2} \mathrm{O}_{3}$ & $6.10-13.30$ & $4.31-21.19$ & $3.48-13.65$ & 12.30 & 17.00 \\
\hline $\mathrm{BaO}$ & $0.00-0.66$ & $0.00-0.19$ & $0.00-0.25$ & 0.00 & 0.00 \\
\hline $\mathrm{CaO}$ & $0.38-2.23$ & $0.00-8.68$ & $0.00-8.68$ & 3.80 & 3.50 \\
\hline $\mathrm{Ce}_{2} \mathrm{O}_{3}$ & $0.00-1.44$ & $0.00-0.02$ & $0.00-0.14$ & 0.00 & 0.00 \\
\hline $\mathrm{Cr}_{2} \mathrm{O}_{3}$ & $0.00-0.55$ & $0.00-0.86$ & $0.00-0.86$ & 0.00 & 0.00 \\
\hline $\mathrm{Cs}_{2} \mathrm{O}$ & $0.00-1.16$ & $0.00-0.26$ & $0.00-0.12$ & 0.00 & 0.00 \\
\hline $\mathrm{FeO}$ & $0.00-8.81$ & $0.00-2.57$ & $0.00-3.99$ & 0.00 & 0.00 \\
\hline $\mathrm{Fe}_{2} \mathrm{O}_{3}$ & $0.00-14.30$ & $0.00-20.77$ & $0.00-20.77$ & 1.20 & 0.30 \\
\hline $\mathrm{K}_{2} \mathrm{O}$ & $0.00-5.73$ & $0.00-7.21$ & $0.00-4.81$ & 0.00 & 0.00 \\
\hline $\mathrm{La}_{2} \mathrm{O}_{3}$ & $0.00-0.42$ & $0.00-0.03$ & $0.00-0.42$ & 0.00 & 0.00 \\
\hline $\mathrm{Li}_{2} \mathrm{O}$ & $2.59-5.16$ & $0.00-5.41$ & $0.00-11.15$ & 3.70 & 5.00 \\
\hline $\mathrm{MgO}$ & $0.00-3.24$ & $0.00-3.79$ & $0.00-1.86$ & 2.00 & 0.00 \\
\hline $\mathrm{MnO}$ & $0.00-3.36$ & $0.00-5.09$ & $0.00-5.09$ & 0.00 & 0.00 \\
\hline $\mathrm{MoO}_{3}$ & $0.00-1.67$ & $0.00-0.02$ & $0.00-0.22$ & 0.00 & 0.00 \\
\hline $\mathrm{Na}_{2} \mathrm{O}$ & $6.42-16.80$ & $4.26-24.43$ & $2.84-24.43$ & 8.30 & 10.70 \\
\hline $\mathrm{Nd}_{2} \mathrm{O}_{3}$ & $0.00-5.96$ & $0.00-0.36$ & $0.00-0.67$ & 0.00 & 0.00 \\
\hline $\mathrm{NiO}$ & $0.00-2.97$ & $0.00-2.57$ & $0.00-1.77$ & 0.00 & 0.00 \\
\hline $\mathrm{P}_{2} \mathrm{O}_{5}$ & $0.00-0.65$ & $0.00-0.59$ & $0.00-3.08^{*}$ & 0.00 & 0.00 \\
\hline $\mathrm{PbO}$ & $0.00-0.25$ & $0.00-0.28$ & $0.00-0.25$ & 0.00 & 0.00 \\
\hline $\mathrm{SiO}_{2}$ & $39.80-59.80$ & $38.72-63.75$ & $37.79-68.50$ & 56.90 & 43.40 \\
\hline $\mathrm{SrO}$ & $0.00-0.45$ & $0.00-0.05$ & $0.00-0.16$ & 0.00 & 0.00 \\
\hline $\mathrm{TiO}_{2}$ & $0.00-3.21$ & $0.00-1.05$ & $0.00-1.71$ & 4.40 & 0.00 \\
\hline $\mathrm{U}_{3} \mathrm{O}_{8}$ & 0.00 & 0.00 & $0.00-5.66$ & 0.00 & 0.00 \\
\hline $\mathrm{ZnO}$ & $0.00-1.46$ & $0.00-0.33$ & $0.00-0.44$ & 0.00 & 0.00 \\
\hline $\mathrm{ZrO}_{2}$ & $0.00-1.80$ & $0.00-1.46$ & $0.00-1.25$ & 0.00 & 0.00 \\
\hline $\begin{array}{c}\text { Fission Products } \\
\text { and Actinides }\end{array}$ & & & N/A & 6.20 & 2.0 \\
\hline
\end{tabular}


$\$$ During development of THERMO ${ }^{\mathrm{TM}}$ it was determined that a minimum of $3 \mathrm{wt} \% \mathrm{Al}_{2} \mathrm{O}_{3}$ was necessary in high $\mathrm{Fe}_{2} \mathrm{O}_{3}$ containing and high $\mathrm{Na}_{2} \mathrm{O}$ containing glasses to avoid phase separation [19]. This is consistent with the known miscibility gap in the $\mathrm{Al}_{2} \mathrm{O}_{3}-\mathrm{Fe}_{2} \mathrm{O}_{3}-\mathrm{Na}_{2} \mathrm{O}-\mathrm{SiO}_{2}$ quaternary system that defines the crystallization of basalt [19].

* During development of glass durability models, glasses with $\mathrm{P}_{2} \mathrm{O}_{5}$ values in excess of $2.6 \mathrm{st} \%$ were shown to exhibit crystalline phase separation (CPS) [20,21,22].

Table III. Oxide Ranges of Viscosity Model and Validation Glasses

\begin{tabular}{|c|c|c|c|c|c|}
\hline $\begin{array}{c}\text { Parameters } \\
\text { and Oxide } \\
(\mathrm{wt} \%)\end{array}$ & $\begin{array}{l}\text { Viscosity } \\
\text { Model }\end{array}$ & $\begin{array}{c}\text { Viscosity } \\
\text { Validation }\end{array}$ & $\begin{array}{l}\text { Parameters } \\
\text { and Oxide } \\
\text { (wt } \%)\end{array}$ & $\begin{array}{l}\text { Viscosity } \\
\text { Model }\end{array}$ & $\begin{array}{c}\text { Viscosity } \\
\text { Validation }\end{array}$ \\
\hline $\begin{array}{c}\text { Temperature } \\
\left({ }^{\circ} \mathrm{C}\right)\end{array}$ & 873-1491 & 803.35-1491 & $\mathrm{La}_{2} \mathrm{O}_{3}$ & $0.00-0.36$ & $0.00-8.62$ \\
\hline $\begin{array}{l}\text { Viscosity } \\
\text { (poise) }\end{array}$ & $\begin{array}{c}10.23- \\
1122.02\end{array}$ & $10.23-11,000$ & $\mathrm{Li}_{2} \mathrm{O}$ & $2.59-6.96$ & $0.00-17.74$ \\
\hline $\mathrm{Al}_{2} \mathrm{O}_{3}$ & $0.00-13.90$ & $0.00-29.02$ & $\mathrm{MgO}$ & $0.49-2.92$ & $0.00-4.80$ \\
\hline $\mathrm{B}_{2} \mathrm{O}_{3}$ & $6.41-12.20$ & $4.33-13.25$ & $\mathrm{MnO}$ & $0.00-3.26$ & $0.00-4.02$ \\
\hline $\mathrm{BaO}$ & $0.00-0.20$ & $0.00-0.50$ & $\mathrm{Na}_{2} \mathrm{O}$ & $5.80-15.80$ & $5.80-16.8$ \\
\hline $\mathrm{CaO}$ & $0.00-1.47$ & $0.00-1.79$ & $\mathrm{NiO}$ & $0.00-2.97$ & $0.00-3.01$ \\
\hline $\mathrm{Cr}_{2} \mathrm{O}_{3}$ & $0.00-0.09$ & $0.00-1.18$ & $\mathrm{SiO}_{2}$ & $45.60-77.04$ & $34.15-77.04$ \\
\hline $\mathrm{Cs}_{2} \mathrm{O}$ & $0.00-0.15$ & $0.00-0.67$ & $\mathrm{SrO}$ & $0.00-0.07$ & $0.00-0.18$ \\
\hline $\mathrm{CuO}$ & $0.00-0.33$ & $0.00-0.51$ & $\mathrm{ThO}_{2}$ & 0.00 & $0.00-0.06$ \\
\hline $\mathrm{Cu}_{2} \mathrm{O}$ & $0.00-0.30$ & $0.00-0.82$ & $\mathrm{TiO}_{2}$ & $0.00-1.78$ & $0.00-3.10$ \\
\hline $\mathrm{FeO}$ & $0.00-7.14$ & $0.00-7.14$ & $\mathrm{U}_{3} \mathrm{O}_{8}$ & 0.00 & $0.00-5.76$ \\
\hline $\mathrm{Fe}_{2} \mathrm{O}_{3}$ & $0.00-14.20$ & $0.00-16.86$ & $\mathrm{ZnO}$ & 0.00 & $0.00-0.21$ \\
\hline $\mathrm{K}_{2} \mathrm{O}$ & $0.00-5.73$ & $0.00-5.84$ & $\mathrm{ZrO}_{2}$ & $0.00-0.99$ & $0.00-2.00$ \\
\hline
\end{tabular}

Table IV. Oxide Ranges of Liquidus Model and Validation Glasses

\begin{tabular}{|c|c|c||c|c|c|}
\hline $\begin{array}{c}\text { Oxide } \\
\text { Species } \\
\text { (wt\%) }\end{array}$ & $\begin{array}{c}\text { Liquidus } \\
\text { Model } \\
\text { Ranges }\end{array}$ & $\begin{array}{c}\text { Validation } \\
\text { Ranges }\end{array}$ & $\begin{array}{c}\text { Oxide } \\
\text { Species } \\
\text { (wt\%) }\end{array}$ & $\begin{array}{c}\text { Liquidus } \\
\text { Model } \\
\text { Ranges }\end{array}$ & $\begin{array}{c}\text { Validation } \\
\text { Ranges }\end{array}$ \\
\hline $\mathrm{Al}_{2} \mathrm{O}_{3}$ & $0.99-14.16$ & $0.00-16.734$ & $\mathrm{Li}_{2} \mathrm{O}$ & $2.49-6.16$ & $0.00-7.499$ \\
\hline $\mathrm{B}_{2} \mathrm{O}_{3}$ & $4.89-12.65$ & $0.00-19.996$ & $\mathrm{MgO}$ & $0.47-2.65$ & $0.00-7.31$ \\
\hline $\mathrm{CaO}$ & $0.31-2.01$ & $0.00-10.3$ & $\mathrm{MnO}$ & $0.74-3.25$ & $0.00-4.00$ \\
\hline $\mathrm{Cr}_{2} \mathrm{O}_{3}$ & $0.00-0.30$ & $0.00-1.2$ & $\mathrm{Na}_{2} \mathrm{O}$ & $5.99-14.90$ & $4.996-22.737$ \\
\hline $\mathrm{FeO}$ & $0.02-6.90$ & $0.02-6.90$ & $\mathrm{NiO}_{2} \mathrm{O}$ & $0.04-3.05$ & $0.00-3.05$ \\
\hline $\mathrm{Fe}_{2} \mathrm{O}_{3}$ & $3.43-16.98$ & $3.43-16.98$ & $\mathrm{SiO}_{2}$ & $41.80-58.23$ & $29.979-58.23$ \\
\hline $\mathrm{K}_{2} \mathrm{O}$ & $0.00-3.89$ & $0.00-4.002$ & $\mathrm{TiO}_{2}$ & $0.00-1.85$ & $0.00-5.003$ \\
\hline
\end{tabular}

\section{PROCESS CONSTRAINTS: SULFATE SOLUBILITY}

Sulfate and sulfate salts are not very soluble in borosilicate waste glass. When the glass is cooled, inclusions and/or phase separation of a sulfate rich phase are often visible in the glass and often a layer of water soluble sulfate is visible on the glass surface. When the glass is 
molten, the molten salt layer known as gall can float on the melt pool surface. Soluble sulfate salts are often enriched in cesium and strontium, which can impact radionuclide release from the cooled glass if the salts are present as inclusions or a frozen gall layer. The alkali and alkaline earth sulfate salts, in conjunction with alkali chlorides, collect on the melt surface as a low melting $\left(600-800^{\circ} \mathrm{C}\right)$, low density, low viscosity melt phase. At moderate concentrations, the salts have a beneficial effect on melting rates. At excessively high feed concentrations, molten alkali sulfates float on the surface of the melt pool or become trapped as inclusions in the glass.

The results of sulfate solubility measurements from both dynamic melter tests and static crucible tests performed with HLW wastes were compared. This data was also compared to Slurry-Fed Melt Rate (SMRF) data generated on HLW melts. In addition, a survey was made of both dynamic and crucible tests for Low Activity Wastes (LAW) and crucible tests performed with commercial soda-lime-silica glasses. Phenomenological observations in the various studies, e.g. completeness or lack of gall and secondary sulfate phases, were categorized into melt conditions representing "at saturation, over saturation, and super saturation." This enabled modeling of the most desirable "at saturation" conditions, e.g. no appearance of a sulfate layer on the melt pool, in relation to undesirable conditions of over saturation (partial melt pool coverage) and super saturation (almost complete melt pool coverage). Sulfate solubility is related to melt polymerization and so the HLW viscosity model given in this study was used to define the sulfate solubility for the various degrees of sulfate saturation $[23,24]$.

\section{PROCESS CONSTRAINT: REDuction/OXidation (REDOX) EQUILIBRIUM}

Control of the REDuction/OXidation (REDOX) equilibrium in the DWPF melter is critical

for processing high level liquid wastes. Foaming, cold cap roll-overs, and off-gas surges all have an impact on pouring and melt rate during processing of waste glass. All of these phenomena can impact waste throughput and attainment. These phenomena are caused by gas-glass disequilibrium when components in the melter feeds convert to glass and liberate gases such as steam, $\mathrm{CO}_{2}, \mathrm{O}_{2}, \mathrm{H}_{2}, \mathrm{NO}_{\mathrm{x}}$, and/or $\mathrm{N}_{2}$. In order to minimize gas-glass disequilibrium a REDOX strategy is used to balance feed reductants and feed oxidants while controlling the REDOX between $0.09 \leq \mathrm{Fe}^{2+} / \Sigma \mathrm{Fe} \leq 0.33$. A Fe ${ }^{+2} / \Sigma \mathrm{Fe}$ ratio $\leq 0.33$ prevents metallic and sulfide rich species from forming nodules that can accumulate on the floor of the melter. Control of foaming, due to deoxygenation of manganic species, is achieved by converting oxidized $\mathrm{MnO}_{2}$ or $\mathrm{Mn}_{2} \mathrm{O}_{3}$ species to $\mathrm{MnO}$ during melter preprocessing. At the lower REDOX ratio of $\mathrm{Fe}^{+2} / \Sigma \mathrm{Fe} \sim$ 0.09 about $99 \%$ of the $\mathrm{Mn}^{+4} / \mathrm{Mn}^{+3}$ is converted to $\mathrm{Mn}^{+2}$ and foaming does not occur.

The REDOX model relates the $\mathrm{Fe}^{+2} / \Sigma \mathrm{Fe}$ ratio of the final glass to the molar concentrations of the oxidants and reductants in the melter feed. The REDOX model is based on Electron Equivalents (EE) that are exchanged during chemical reduction (making an atom or molecule less positive by electron transfer) and oxidation (making an atom or molecule more positive by electron transfer). Therefore, the number of electrons transferred for each REDOX reaction can be summed and an Electron Equivalents term for each organic and oxidant species defined $[25,26,27]$. The model accounts for reoxidation of the manganese by nitrate salts in the cold cap.

\section{CONCLUSIONS}


At the Savannah River Site (SRS) actual HLW tank waste has been processed into a stable borosilicate glass waste form since 1996 using a unique "feed forward" statistical process control (SPC) without the necessity of rework or melter outages due to incorrect process parameters. The property models are mechanistic. The mechanistic models have been validated over composition regions well outside of the regions for which they were developed because they are based on known mechanisms. This affords the ability to use these models for the broader composition ranges of LLW, TRU, and mixed wastes.

\section{ACKNOWLEDGMENTS}

This paper was prepared in connection with work done under Contract No. DE-AC0996SR18500 with the U.S. Department of Energy (DOE).

\section{REFERENCES}

1 C.M. Jantzen, J. Non-Crystalline Solids, 84, 215-225 (1986).

2 C.M. Jantzen, Ceram. Trans., V. 23, Am. Ceram. Soc., Westerville, OH, 37-51 (1991).

3 C.M. Jantzen, and K.G. Brown, Am. Ceramic Society Bulletin, 72, 55-59 (May, 1993).

4 K.G. Brown, R.L. Postles, and R.E. Edwards, Ceram. Trans., V. 23, Am. Ceram. Soc., Westerville, OH, 559568 (1991).

5 C.M. Jantzen, K.G. Brown, T.B. Edwards, and J.B. Pickett, U.S. Patent \#5,846,278, (December 1998).

6 C.M. Jantzen, J.B. Pickett, K.G. Brown, T.B. Edwards, and D.C. Beam, U.S. DOE Report WSRC-TR-930672, Westinghouse Savannah River Co., Savannah River Technology Center, Aiken, SC, 464p. (Sept. 1995).

7 C.M. Jantzen, and J.M. Pareizs, (accepted J. Nucl. Mat.).

8 H.C. Helgeson, W.M. Murphy, and P. Aagaard, Geochimica et Cosmochimica Acta, 48, 2405-2432 (1984).

9 E.H. Oelkers and S.R. Sislason, Geochim. Cosmochim. Acta, 65 [21], 3671-3681 (2001).

10 S.L. Marra, and C.M. Jantzen, U.S. DOE Report WSRC-TR-92-142, Westinghouse Savannah River Co., Savannah River Technology Center, Aiken, SC, 38p (May, 1992).

11 C.M. Jantzen, N.E. Bibler, D.C. Beam, and M.A. Pickett, U.S. DOE Report WSRC-TR-92-346, Rev.1, Westinghouse Savannah River Co., Savannah River Technology Center, Aiken, SC, 92p (February, 1993).

12 C.M. Jantzen, N.E. Bibler, D.C. Beam, D.C. and M.A. Pickett, Ceram. Trans. V. 39, Am. Ceram. Soc., Westerville, OH, 313-322 (1994).

13 C.M. Jantzen, K.G. Brown, J.B. Pickett, and G.L. Ritzhaupt, U.S. DOE Report WSRC-TR-2000-00339, Westinghouse Savannah River Co., Savannah River Technology Center, Aiken, SC (September 30, 2000).

14 P. Van Iseghem and B. Grambow, Sci. Basis for Nuclear Waste Management XI, J.J. Apted and R.E. Westerman (Eds.), Materials Research Society, Pittsburgh, PA, 631-639 (1987).

15 C.M. Jantzen, U.S. Patent \#5,102,439, (April, 1992).

16 C.M. Jantzen, U.S. DOE Report WSRC-TR-2004-00311 (February 2005).

17 C.M. Jantzen, and K.G. Brown, J. Am. Ceramic Soc., 90 [6], 1866-1879 (2007).

18 C.M. Jantzen, and K.G. Brown, J. Am. Ceramic Soc., 90 [6], 1880-1891 (2007).

19 C.M. Jantzen, C.M. and Brown, K.G., Ceram. Trans., V. 107, 289-300 (2000).

20 C.M. Jantzen, U.S. DOE Report 86-389 (1986).

21 C.M. Jantzen, K.G. Brown, and J.B. Pickett, Ceram. Trans., V. 119, Amer. Ceram. Soc., Westerville, OH, VI, 271-280 (2001).

22 C.M. Jantzen, K.G. Brown, J.B. Pickett, and G.L. Ritzhaupt, U.S. DOE Report WSRC-TR-2000-00339 (Sept. 2000).

23 C.M. Jantzen, and M.E. Smith, U.S. DOE Report WSRC-TR-2003-00518 (January 2004).

24 C.M. Jantzen, D.K. Peeler, and M.E. Smith, M.E. Ceram. Trans. 168, 141-151 (2005).

25 C.M. Jantzen, J.R. Zamecnik, D.C. Koopman, C.C. Herman, and J.B. Pickett, U.S. DOE Report WSRC-TR2003-00126, Rev.0 (May 2003). 
WSRC-STI-2007-00238

Revision 0

26 C.M. Jantzen, D.C. Koopman, C.C. Herman, J.B. Pickett and J.R. Zamecnik, Ceram. Trans. V. 155, Am. Ceram. Soc., Westerville, OH, 79-91 (2004).

27 C.M. Jantzen, and M.E. Stone, US DOE Report WSRC-STI-2006-00066 (2007). 